\title{
Tobacco use among School-going Adolescents in Comoros: A Secondary Analysis of the 2015 Comoros Global Youth Tobacco Survey.
}

Peter Bai James ( $\nabla$ jamepeb@yahoo.com )

University of Sierra Leone College of Medicine and Allied Health Sciences https://orcid.org/0000-0002-6373-5704

\section{Said Abasse Kassim}

Laval University: Universite Laval

John Alimamy Kabba

Xi'an Jiaotong University

Chenai Kitchen

Xi'an Jiaotong University

\section{Research}

Keywords: Tobacco use, Adolescents, Comoros, Low- and Middle-Income Countries, Africa

Posted Date: February 25th, 2022

DOI: https://doi.org/10.21203/rs.3.rs-838524/v2

License: (c) (i) This work is licensed under a Creative Commons Attribution 4.0 International License. Read Full License

Version of Record: A version of this preprint was published at BioMed Research International on March 8th, 2022. See the published version at https://doi.org/10.1155/2022/7134340. 


\section{Abstract}

Background: Tobacco use among adolescents has long-term adverse health consequences, especially during adulthood. Currently, little is known about tobacco use behaviour among adolescents in Comoros. Our study aims to estimate the prevalence and identify key factors associated with tobacco use among adolescents in Comoros using the 2015 Comoros Global Youth Tobacco Survey data.

Methods: A national cross-sectional survey secondary data of 2,810 eligible school-going adolescents aged between 11-17 years was analysed. Complex sample logistic regression analyses to determine the correlates of current cigarette smoking and current use of non-cigarette tobacco products.

Results: The overall prevalence of current cigarette smoking was 14.3\% [males (18.5\%), females (9.9\%)]. The prevalence of current use of non-cigarette tobacco products was 5.8\% [males (6.7\%), females (4.9\%)]. Being male $(A O R=2.24 ; 95 \% \mathrm{Cl}: 1.39-3.63)$, exposure to secondhand smoke inside (AOR=3.88;95\%Cl:2.84-5.31) and outside (AOR= $1.49 ; 95 \% \mathrm{Cl}: 1.08-2.03)$ their home and exposure to tobacco industry promotion ( $\mathrm{AOR}=2.90 ; 95 \% \mathrm{Cl}: 2.21-3.80)$ were associated with current cigarette use among school-going adolescents. However, parental smoke (AOR=1.20; 95\% Cl:0.78-1.87) and not exposed to anti-smoking education in schools (AOR= 0.97;95\% Cl:0.76-1.22) were not associated with current cigarette use. On the other hand, being male ( $\mathrm{AOR}=1.24 ; 95 \% \mathrm{Cl}: 0.82-1.86)$ was not associated with the current use of noncigarette tobacco products. Adolescents who were exposed to tobacco industry promotion $(\mathrm{AOR}=.2 .58 ; 95 \% \mathrm{Cl}: 1.54-4.32)$ and not exposed to anti-smoking education in school (AOR=0.52;95\%Cl:0.32-0.85) were more and less likely associated with non-cigarette tobacco use.

Conclusion: One in seven school-going adolescents smoke cigarettes, and approximately one in 20 school-going adolescents use non-cigarette tobacco products in Comoros. Exposure to secondhand smoke within and outside the home and exposure to tobacco industry promotion were associated with tobacco use in school-going adolescents in Comoros. Our findings suggest the need for adolescent-friendly gender-sensitive tobacco interventions, including strengthening existing tobacco control laws to prevent and reduce tobacco use among school-going adolescents in Comoros.

\section{Background}

Globally, tobacco use is considered a significant risk factor for non-communicable diseases, including nicotine addiction, and a means through which youths are introduced to using other illegal substances(1-3). In recent years-a , low- and middle-income countries have started experiencing the public health impact of non-communicable diseases related to the increased use of tobacco products(4). This increased utilisation rate has been attributed to the influx of transnational tobacco companies in these countries due to weak tobacco legislations and policies, low levels of education, and demographic shift in the population in these areas $(5,6)$. Studies conducted in African countries have reported increasing use of tobacco products among adolescents(7-9). Factors such as being male, exposure to secondhand smoking within and outside the home, peer influence and exposure, to tobacco industry promotion, advertisement, and sponsorship have been associated with use tobacco products among adolescents(710).

Comoros is an archipelago located in the Indian Ocean, north of the Mozambique Channel and northeast Madagascar, and composed of three main islands (Grande Comore, Anjouan and Mohéli)(11), Comoros is a developing country with $25 \%$ of poor population below the country's poverty line, and is known to have poor health outcomes such as high maternal and child mortality compared to its neighbouring island nations of Mauritius and 
Seychelles(12,13). In 2018, one in five adults in Comoros used tobacco, which creates a future public health threat(14). This public health threat is compounded by the fact that non-communicable disease is a major public health concern in $\operatorname{Comoros}(15,16)$. In $2008,25.4 \%$ of the population had high blood pressure, $4.8 \%$ had diabetes, and $25.9 \%$ had high cholesterol levels(15). Death due to non-communicable diseases has increased from $42 \%$ in 2015 to 45\% in 2019(17). Similar to other African countries, Comoros, in 2006, became a signatory to the World Health Organization (WHO)Framework Convention on Tobacco Control (FCTC). In line with the WHO-FCTC framework, Comoros enacted three laws since 2010 that regulate tobacco product use(18). These regulations include the use of smoke-free places, tobacco advertising, promotion and sponsorship, and tobacco packaging and labelling(18). Despite the impact of these laws in reducing tobacco use prevalence from $30.4 \%$ in 2007 to $19.5 \%$ in 2018 , tobacco use remains high(14). This relatively high use maybe due to ambiguity in the interpretation of some of the laws. For example, even though smoking is banned in all public places, the legal instruments are hard to explain due to discrepancies and conflicting provisions in the law(18). Another reason for the high use of tobacco maybe due to non-adherence to the WHO- FCTC recommendation. For instance, Comoros currently levies a $25 \%$ excise tax on the retail price of tobacco products, which is far below the WHO tobacco excise taxes recommended threshold of $70 \%$ on all the retail price of tobacco products(18).

Given that most adult smokers initiate smoking during adolescence, it highlights the need to understand the tobacco use behaviour among adolescents(5). Currently, tobacco use research in Comoros have focussed on adults(15), with little or no research on adolescents who account for more than half of the population(13). Therefore, this study aims to estimate the prevalence and identify key factors associated with tobacco use among adolescents in Comoros using data obtained in the 2015 Comoros Global Youth Tobacco Survey. An understanding of tobacco use behaviour among adolescents will inform public health policies and interventions designed to prevent adolescents' tobacco use initiation and transition into future adult smokers.

\section{Methods}

\section{Study Design and Comoros Global Youth Tobacco Survey}

We used data obtained from the Comoros Global Youth Tobacco Survey (GYTS) administered in 2015 by the Ministry of Health. The survey collected tobacco use information from 2,810 eligible school-going adolescents aged between 11-17 years. GYTS uses a global standardised methodology that measures and tracks key tobacco control indicators(19). The survey is designed to obtain relevant information on tobacco use prevalence and its associated determinants such as secondhand smoke (SHS), pro-and anti-tobacco media and advertising, access to and availability of tobacco products, and knowledge and attitudes regarding tobacco use. Details of the survey methodology have been described in previous studies(19). Basically, the survey methodology involves a two-stage sample design in which schools are chosen with a probability proportional to the enrolment size in the first stage. In the second stage, classes are selected randomly within these schools. Students in the selected classes were eligible and had an equal chance of being chosen. The overall response rate was $83.8 \%(20)$. This study adheres to STROBE guidelines for cross-sectional studies (Supplementary file1)

\section{Study measures}

Two outcome measures were used to measure tobacco use among adolescents in Comoros. These include current cigarette smoking and the current use of non-cigarette tobacco products. Current cigarette smoking status was determined by respondents' choice of one or more days with question, "During the past 30 days, on how many days did you smoke cigarettes?" Current use of non-cigarette tobacco products was determined by recording the 
respondent choice on any of the following two questions - "During the past 30 days, did you use any form of smoked tobacco products other than cigarettes (e.g., cigars, water pipes, cigarillos, little cigars, pipes)?" and "During the past 30 days (one month), did you use any form of smokeless tobacco products (e.g., chewing tobacco, snuff, dip)?". The following measures were considered as independent factors based on the available literature $(7-9,21)$. These factors were constructed from 28 questions. This includes age, sex, average spending per week, parental or peer smoking, exposure to secondhand smoke inside or outside the home, exposure to smoking or anti-smoking media messages, exposure to tobacco industry promotions, perceptions about smoking, knowledge about harmful effects of smoking and SHS as well as attitudes toward smoking ban(20). Table 1 gives further details of how the dependent and independent variables were defined and dichotomized in this study.

Table 1: Study measures, survey items with responses, 2015 Comoros Global Youth Tobacco Survey (GYTS) 


\begin{tabular}{|c|c|c|c|c|}
\hline Study measure & GYTS survey items & $\begin{array}{l}\text { GYTS item } \\
\text { responses }\end{array}$ & Dichotomized measure & \\
\hline $\begin{array}{l}\text { Dependent } \\
\text { variable: } \\
\text { current } \\
\text { cigarette use }\end{array}$ & $\begin{array}{l}\text { During the past } 30 \text { days, } \\
\text { on how many days did } \\
\text { you smoke cigarettes? }\end{array}$ & $\begin{array}{l}0 \text { days } \\
1 \text { or } 2 \text { days } \\
3 \text { to } 5 \text { days } \\
6 \text { to } 9 \text { days } \\
10 \text { to } 19 \text { days } \\
20 \text { to } 29 \text { days } \\
\text { All } 30 \text { days }\end{array}$ & $\begin{array}{l}\text { No- } 0 \text { days } \\
\text { Yes- } 1 \text { or more days }\end{array}$ & \\
\hline \multirow[t]{2}{*}{$\begin{array}{l}\text { Current use of } \\
\text { non-cigarette } \\
\text { tobacco } \\
\text { products }\end{array}$} & $\begin{array}{l}\text { During the past } 30 \text { days, } \\
\text { did you use any form of } \\
\text { smoked tobacco } \\
\text { products other than } \\
\text { cigarettes (such as cigar, } \\
\text { pipe water pipe and } \\
\text { shisha)? }\end{array}$ & $\begin{array}{l}\text { Yes } \\
\text { No }\end{array}$ & $\begin{array}{l}\text { Yes } \\
\text { No }\end{array}$ & \\
\hline & $\begin{array}{l}\text { During the past } 30 \text { days, } \\
\text { did you use any form of } \\
\text { smokeless tobacco } \\
\text { products (e.g. chewing } \\
\text { tobacco, snuff, dip)? }\end{array}$ & $\begin{array}{l}\text { Yes } \\
\text { No }\end{array}$ & $\begin{array}{l}\text { Yes } \\
\text { No }\end{array}$ & \\
\hline \multicolumn{5}{|l|}{$\begin{array}{l}\text { Independent } \\
\text { variables }\end{array}$} \\
\hline Age & How old are you? & $\begin{array}{l}11 \text { years old or } \\
\text { younger } \\
12 \text { years old } \\
13 \text { years old } \\
14 \text { years old } \\
15 \text { years old } \\
16 \text { years old } \\
17 \text { years old or } \\
\text { older }\end{array}$ & $\begin{array}{l}\leq 12 \text { years } \\
13-15 \text { years } \\
\geq 16 \text { years }\end{array}$ & \\
\hline Sex & What is your sex? & $\begin{array}{l}\text { Male } \\
\text { female }\end{array}$ & $\begin{array}{l}\text { Male } \\
\text { female }\end{array}$ & \\
\hline Grade / form & $\begin{array}{l}\text { In what grade/form are } \\
\text { you? }\end{array}$ & $\begin{array}{l}6 \text { eme } \\
5 \text { eme } \\
4 \text { eme } \\
3 \text { eme }\end{array}$ & $\begin{array}{l}6 \text { eme } \\
5 \text { eme } \\
4 \text { eme } \\
3 \text { eme }\end{array}$ & \\
\hline $\begin{array}{l}\text { Money to be } \\
\text { spent on } \\
\text { average week }\end{array}$ & $\begin{array}{l}\text { During an average week, } \\
\text { how much money do you } \\
\text { have that you can spend } \\
\text { on yourself, however you } \\
\text { want? }\end{array}$ & $\begin{array}{l}\begin{array}{l}\text { I usually don't } \\
\text { have any } \\
\text { spending } \\
\text { money }\end{array} \\
\text { Less than } 500 \\
\text { Fr } \\
\text { [500-1000] } \\
{[1001-2500]} \\
{[2501-5000]} \\
{[5001-7500]} \\
{[7501 \text { and + }}\end{array}$ & $\begin{array}{l}\text { No Money- I usually } \\
\text { don't have any } \\
\text { spending money } \\
\text { Have money- any } \\
\text { other responses for } \\
\text { any of the remaining } \\
\text { seven items }\end{array}$ & \\
\hline $\begin{array}{l}\text { Parental } \\
\text { smoking }\end{array}$ & $\begin{array}{l}\text { How often do you see } \\
\text { your father (stepfather }\end{array}$ & $\begin{array}{l}\text { Don't } \\
\text { have/Don't see }\end{array}$ & $\begin{array}{l}\text { No- Don't have/Don't } \\
\text { see this person and }\end{array}$ & $\begin{array}{l}\text { No- no for } \\
\text { both }\end{array}$ \\
\hline
\end{tabular}

Page 5/20 


\begin{tabular}{|c|c|c|c|c|}
\hline & $\begin{array}{l}\text { or mother's partner) } \\
\text { smoking in your home? }\end{array}$ & $\begin{array}{l}\text { this person } \\
\text { About every } \\
\text { day } \\
\text { Sometimes } \\
\text { Never }\end{array}$ & $\begin{array}{l}\text { Never } \\
\text { Yes- About every day } \\
\text { and Sometimes }\end{array}$ & \multirow[b]{2}{*}{$\begin{array}{l}\text { Yes - for } \\
\text { both } \\
\text { dichotomized } \\
\text { items }\end{array}$} \\
\hline & $\begin{array}{l}\text { How often do you see } \\
\text { your mother } \\
\text { (stepmother or father's } \\
\text { partner) smoking in } \\
\text { your home }\end{array}$ & $\begin{array}{l}\text { Don't } \\
\text { have/Don't see } \\
\text { this person } \\
\text { About every } \\
\text { day } \\
\text { Sometimes } \\
\text { Never }\end{array}$ & $\begin{array}{l}\text { No- Don't have/Don't } \\
\text { see this person and } \\
\text { Never } \\
\text { Yes- About every day } \\
\text { and Sometimes }\end{array}$ & \\
\hline $\begin{array}{l}\text { SHSb } \\
\text { exposure in } \\
\text { your home }\end{array}$ & $\begin{array}{l}\text { During the past } 7 \text { days, } \\
\text { on how many days has } \\
\text { anyone smoked inside } \\
\text { your home, in your } \\
\text { presence? }\end{array}$ & $\begin{array}{l}0 \text { days } \\
1 \text { to } 2 \text { days } \\
3 \text { to } 4 \text { days } \\
5 \text { to } 6 \text { days } \\
7 \text { days }\end{array}$ & $\begin{array}{l}\text { No- } 0 \text { days } \\
\text { Yes- } 1 \text { to } 2 \text { days } \\
3 \text { to } 4 \text { days } \\
5 \text { to } 6 \text { days } \\
7 \text { days }\end{array}$ & \\
\hline \multirow[t]{3}{*}{$\begin{array}{l}\text { SHSb } \\
\text { exposure } \\
\text { outside home }\end{array}$} & $\begin{array}{l}\text { During the past } 7 \text { days, } \\
\text { on how many days has } \\
\text { anyone smoked in your } \\
\text { presence, inside any } \\
\text { enclosed public } \\
\text { place, other than your } \\
\text { home (such as office, } \\
\text { school, shops, } \\
\text { restaurants, cinemas, } \\
\text { night club)? }\end{array}$ & $\begin{array}{l}0 \text { days } \\
1 \text { to } 2 \text { days } \\
3 \text { to } 4 \text { days } \\
5 \text { to } 6 \text { days } \\
7 \text { days }\end{array}$ & $\begin{array}{l}\text { No- } 0 \text { days } \\
\text { Yes- } 1 \text { to } 2 \text { days } \\
3 \text { to } 4 \text { days } \\
5 \text { to } 6 \text { days } \\
7 \text { days }\end{array}$ & \multirow{3}{*}{$\begin{array}{l}\text { No- no for } \\
\text { all three } \\
\text { dichotomized } \\
\text { items } \\
\\
\text { Yes - for all } \\
\text { three } \\
\text { dichotomized } \\
\text { items }\end{array}$} \\
\hline & $\begin{array}{l}\text { During the past } 7 \text { days, } \\
\text { on how many days has } \\
\text { anyone smoked in your } \\
\text { presence, inside any } \\
\text { public } \\
\text { transportation vehicles, } \\
\text { such as trains, buses, or } \\
\text { taxicabs? }\end{array}$ & $\begin{array}{l}\text { I did not use } \\
\text { public } \\
\text { transportation } \\
\text { during the past } \\
7 \text { days } \\
\text { I used public } \\
\text { transportation, } \\
\text { but no one } \\
\text { smoked in my } \\
\text { presence } \\
1 \text { to } 2 \text { days } \\
3 \text { to } 4 \text { days } \\
5 \text { to } 6 \text { days } \\
7 \text { days }\end{array}$ & $\begin{array}{l}\text { No-" I did not use } \\
\text { public transportation } \\
\text { during the past } 7 \\
\text { days" and "I used } \\
\text { public transportation, } \\
\text { but no one smoked in } \\
\text { my presence" } \\
\text { Yes-1 to } 2 \text { days } \\
3 \text { to } 4 \text { days } \\
5 \text { to } 6 \text { days } \\
7 \text { days }\end{array}$ & \\
\hline & $\begin{array}{l}\text { During the past } 7 \text { days, } \\
\text { on how many days has } \\
\text { anyone smoked in your } \\
\text { presence, at any outdoor } \\
\text { public place } \\
\text { (such as playgrounds, } \\
\text { sidewalks, entrances to } \\
\text { buildings, parks, } \\
\text { beaches, vehicle)? }\end{array}$ & $\begin{array}{l}0 \text { days } \\
1 \text { to } 2 \text { days } \\
3 \text { to } 4 \text { days } \\
5 \text { to } 6 \text { days } \\
7 \text { days }\end{array}$ & $\begin{array}{l}\text { No- } 0 \text { days } \\
\text { Yes- } 1 \text { to } 2 \text { days } \\
3 \text { to } 4 \text { days } \\
5 \text { to } 6 \text { days } \\
7 \text { days }\end{array}$ & \\
\hline $\begin{array}{l}\text { Exposure to } \\
\text { antismoking } \\
\text { media } \\
\text { messages }\end{array}$ & $\begin{array}{l}\text { During the past } 30 \text { days, } \\
\text { how many } \\
\text { antismoking media } \\
\text { messages (e.g., } \\
\text { television, } \\
\text { radio, billboards, } \\
\text { posters, newspapers, }\end{array}$ & $\begin{array}{l}\text { Yes } \\
\text { No }\end{array}$ & $\begin{array}{l}\text { Yes } \\
\text { No }\end{array}$ & $\begin{array}{l}\text { No- no for } \\
\text { both } \\
\text { dichotomized } \\
\text { items }\end{array}$ \\
\hline
\end{tabular}




\begin{tabular}{|c|c|c|c|c|}
\hline & $\begin{array}{l}\text { magazines, } \\
\text { movies) have you seen? }\end{array}$ & & & $\begin{array}{l}\text { Yes - for } \\
\text { both } \\
\text { dichotomized } \\
\text { items } \\
\end{array}$ \\
\hline $\begin{array}{l}\text { Exposure to } \\
\text { smoking } \\
\text { media } \\
\text { messages in } \\
\text { the media } \\
\end{array}$ & $\begin{array}{l}\text { During the past } 30 \text { days, } \\
\text { did you see any people } \\
\text { using tobacco on TV, in } \\
\text { videos, or in movies? }\end{array}$ & $\begin{array}{l}\text { I did not watch } \\
\text { TV, videos or } \\
\text { movies } \\
\text { Yes } \\
\text { No }\end{array}$ & $\begin{array}{l}\text { Yes= "Yes" } \\
\text { No= "I did not watch } \\
\text { TV, videos or movies" } \\
\text { and "No" }\end{array}$ & \\
\hline \multirow[t]{2}{*}{\begin{tabular}{|l} 
Favour \\
toward \\
smoking ban
\end{tabular}} & $\begin{array}{l}\text { Are you in favor of } \\
\text { banning smoking inside } \\
\text { enclosed public places } \\
\text { (such as schools, shops, } \\
\text { restaurants, } \\
\text { supermarket, shopping } \\
\text { centers, movie theaters, } \\
\text { youth homes ...)? } \\
\end{array}$ & $\begin{array}{l}\text { No } \\
\text { Yes }\end{array}$ & \begin{tabular}{|l|} 
No \\
Yes
\end{tabular} & \\
\hline & $\begin{array}{l}\text { Are you in favor of } \\
\text { banning smoking at } \\
\text { outdoor public places } \\
\text { (such as stadium, public } \\
\text { place, recreation } \\
\text { areas, sidewalks, } \\
\text { entrances to buildings, } \\
\text { beaches)? } \\
\end{array}$ & $\begin{array}{l}\text { No } \\
\text { Yes }\end{array}$ & $\begin{array}{l}\text { No } \\
\text { Yes }\end{array}$ & \\
\hline $\begin{array}{l}\text { Knowledge } \\
\text { about harmful } \\
\text { effects of SHS }\end{array}$ & $\begin{array}{l}\text { Do you think the smoke } \\
\text { from other people's } \\
\text { cigarettes is harmful to } \\
\text { you? }\end{array}$ & $\begin{array}{l}\text { Definitely not } \\
\text { Probably not } \\
\text { Probably yes } \\
\text { Definitely yes }\end{array}$ & $\begin{array}{l}\text { No "Definitely not" for } \\
\text { both } \\
\text { items } \\
\text { Yes - any other } \\
\text { responses } \\
\text { for either item }\end{array}$ & \\
\hline \multirow[t]{2}{*}{\begin{tabular}{|l|} 
Tobacco \\
industry \\
promotion
\end{tabular}} & $\begin{array}{l}\text { Do you have something } \\
\text { (t-shirt, pen, backpack, } \\
\text { etc.) } \\
\text { with a cigarette brand } \\
\text { logo on it? }\end{array}$ & $\begin{array}{l}\text { No } \\
\text { Yes }\end{array}$ & $\begin{array}{l}\text { No } \\
\text { Yes }\end{array}$ & $\begin{array}{l}\text { No- no for } \\
\text { both } \\
\text { dichotomized } \\
\text { items }\end{array}$ \\
\hline & $\begin{array}{l}\text { Has a (cigarette } \\
\text { representative) ever } \\
\text { offered } \\
\text { you a free cigarette? }\end{array}$ & $\begin{array}{l}\text { No } \\
\text { Yes }\end{array}$ & $\begin{array}{l}\text { No } \\
\text { Yes }\end{array}$ & $\begin{array}{l}\text { Yes - for } \\
\text { both } \\
\text { dichotomized } \\
\text { items }\end{array}$ \\
\hline $\begin{array}{l}\text { Antismoking } \\
\text { school } \\
\text { education }\end{array}$ & $\begin{array}{l}\text { During the past } 12 \\
\text { months, were you taught } \\
\text { in any of your classes } \\
\text { about the dangers of } \\
\text { tobacco use? }\end{array}$ & $\begin{array}{l}\text { No } \\
\text { I don't know } \\
\text { Yes }\end{array}$ & $\begin{array}{l}\text { No- No } \\
\text { I don't know } \\
\text { Yes- Yes }\end{array}$ & \\
\hline
\end{tabular}

\section{Ethical Consideration}

No ethics approval was required for this study since it is a secondary analysis of the Comoros Global Youth Tobacco Survey (GYTS) dataset, which is available in the public domain (Available 
at https://extranet.who.int/ncdsmicrodata/index.php/catalog/123). Ethical procedures were conducted by institutions that funded, commissioned, and managed the survey prior to collecting the primary data, and that includes the Ministry of Health Comoros. Informed consent was obtained from the school authorities involved in the survey and the parents and guardians of adolescents enrolled in the survey. All data were anonymized prior to the authors receiving the data for secondary analysis. A preprint of this study has previously been published(22)

\section{Data Analysis}

We used the Statistical Package for Social Science (IBM, SPSS 27.0) to analyse our data. To estimate the prevalence of current cigarette smoking and current use of non-cigarette tobacco products, we reported weighted data to adjust for sampling design effect and missing values due to non-responses at school, class, and student levels. All analyses (descriptive and inferential) were conducted using complex samples icon on SPSS to account for complex sampling design and for incorporating weights. Due to established gender differences regarding tobacco use, we conducted separate analyses for male and female adolescents. We employed complex sample logistic regression analyses to determine the correlates of current cigarette smoking and current use of non-cigarette tobacco products. We reported an adjusted odds ratio (AOR) and 95\% confidence interval (Cl). A p-value less than 0.05 ( $p$-value $<0.05$ ) was considered statistically significant. We used the Hosmer and Lemeshow Test to test the fitness of our models. Hosmer and Lemeshow Test for current cigarette smoker was $(p=0.212)$ and for current user of noncigarette tobacco products was $p=0.497$. All models were checked for possible multicollinearity using variance Inflation factor (VIF). The multicollinearity test for the explanatory variables for current cigarette smokers was (mean VIF= 1.096, Min $\mathrm{VIF}=1.017$, Max VIF=1.239) and current user of noncigarette tobacco products was (mean VIF= 1.093, Min $\mathrm{VIF}=1.016$, Max $\mathrm{VIF}=1.238$ )

\section{Results}

\section{Characteristics of the study population}

Two thousand eight hundred and ten school-going adolescents took part in the study. Close to half of them were males $(n=1310,48.1 \%)$ and more than half were between the age of $13-15$ years $(n=1551,55.3 \%)$. Close quarter of were exposure to parental smoking $(n=584 ; 21.2 \%)$. More than a quarter $(n=793,28.8 \%)$ and close to two-thirds $(n=1636,59.6 \%)$ were exposed to secondhand smoke in and outside their homes, respectively. Please see Table 2 for details.

Table2: Characteristics of the Study population, Comoros Global Youth Tobacco Survey, 2015 (N= 2,810) 


\begin{tabular}{|l|l|l|}
\hline Age & Unweighted count & Weighted \% \\
\hline$\leq 12$ years & 276 & 9.5 \\
\hline $13-15$ years & 1551 & 55.3 \\
\hline$\geq 16$ years & 938 & 35.2 \\
\hline Sex & & \\
\hline Male & 1310 & 48.1 \\
\hline Female & 1479 & 51.9 \\
\hline Grade & & \\
\hline 6 eme & 954 & 31.5 \\
\hline 5 eme & 665 & 25.1 \\
\hline 4 eme & 630 & 21.7 \\
\hline 3 eme & 546 & 21.8 \\
\hline Possession of Average spending money/week & & \\
\hline I have & 1976 & 70.2 \\
\hline I do not have & 834 & 29.8 \\
\hline Parental Smoke (Yes) & 584 & 21.2 \\
\hline SHS exposure inside home (Yes) & 793 & 28.8 \\
\hline SHS exposure outside home (Yes) & 1636 & 59.6 \\
\hline Exposure to smoking media messages (Yes) & 1213 & 44.3 \\
\hline Exposure to anti-smoking media messages (Yes) & 1373 & 50.6 \\
\hline Exposure to tobacco industry promotion (Yes) & 543 & 21.5 \\
\hline Knowledge about harmful effects of SHS(Yes) & 1918 & 69.7 \\
\hline school anti-smoking education (Yes) & 669 & 25.3 \\
\hline Favour toward smoking ban indoor and outdoor (Yes) & 2041 & 74.6 \\
\hline
\end{tabular}

\section{Prevalence of current cigarette and non-cigarette tobacco products use}

Table 3 describes the prevalence of current cigarette smoke and non-cigarette tobacco product use among schoolgoing adolescents in Comoros based on the 2015GYTS. The overall prevalence of current cigarette smoking was $(n=400,14.3 \%)$ with a significant difference between males $(n=246,18.5 \%)$ and females $(n=143,9.9 \%)$. The prevalence of current cigarette smoking was highest among adolescents exposed to secondhand smoke outside the home $(n=305,78.2 \%)$, followed by those who favoured the smoking ban $(n=284,76.6 \%)$. A similar pattern was observed among male students. Among females, the prevalence of current cigarette smoking was highest among those with income $(n=106,74.1 \%)$, followed by exposure to secondhand smoke outside the home $(n=101,72.7 \%)$.

The overall prevalence of current non-cigarette tobacco products use was $(n=145,5.8 \%)$ with little difference between males $(n=81,6.7 \%)$ and females $(n=64,4.9 \%)$. The highest prevalence of current use of non-cigarette tobacco products was observed among those who were in favour toward smoking ban $(n=111,78.6 \%)$ and this was the same among males and females. The least prevalence was observed among students aged 12 years and below $(n=7,5.8 \%)$. followed by those exposed to SHS outside the home (70.3\%). A similar pattern was observed among males and females (See Table 3 for details).

Table 3: Prevalence of current cigarette smoking, and non-cigarette tobacco products use among male and female adolescents in Comoros, Global Youth Tobacco Survey, $2015(N=2,810)$ 


\begin{tabular}{|c|c|c|c|c|c|c|}
\hline \multirow{2}{*}{$\begin{array}{l}\text { Characteristic } \\
\mathrm{n}\left(\%^{\mathrm{a})}\right.\end{array}$} & \multicolumn{3}{|c|}{ Current cigarette smoker } & \multicolumn{3}{|c|}{$\begin{array}{l}\text { Current user of noncigarette } \\
\text { tobacco products }\end{array}$} \\
\hline & $\begin{array}{l}\text { Total } \\
\mathrm{n}\left(\%^{\mathrm{a}}\right) \\
400(14.3)\end{array}$ & $\begin{array}{l}\text { Male } \\
\mathrm{n}\left(\%^{\mathrm{a}}\right) \\
246(18.5) \\
\end{array}$ & $\begin{array}{l}\text { Female } \\
\mathrm{n}\left(\%^{\mathrm{a}}\right) \\
143(9.9) \\
\end{array}$ & $\begin{array}{l}\text { Total } \\
\mathrm{n}\left(\%^{\mathrm{a}}\right) \\
145(5.8)\end{array}$ & $\begin{array}{l}\text { Male } \\
\mathrm{n}(\% \mathrm{a}) \\
81(6.7)\end{array}$ & $\begin{array}{l}\text { Female } \\
\mathrm{n}\left(\%^{\mathrm{a}}\right) \\
64(4.9)\end{array}$ \\
\hline \multicolumn{7}{|l|}{ Age } \\
\hline$\leq 12$ years & $17(4.2)$ & $9(3.5)$ & $7(4.9)$ & $7(5.0)$ & $4(5.0)$ & $3(5.0)$ \\
\hline 13-15 years & $\begin{array}{l}209 \\
(53.4)\end{array}$ & $121(48.9)$ & $85(61.9)$ & $66(45.4)$ & $35(43.4)$ & $31(48.6)$ \\
\hline$\geq 16$ years & $161(42.5)$ & $113(47.6)$ & $45(33.2)$ & $65(49.6)$ & $37(51.7)$ & $27(46.3)$ \\
\hline \multicolumn{7}{|l|}{ Grade } \\
\hline 6 eme & $\begin{array}{l}142 \\
(33.3)\end{array}$ & $97(35.8)$ & $41(28.5)$ & $42(25.7)$ & $\begin{array}{l}29 \\
(31.6)\end{array}$ & $\begin{array}{l}12 \\
(17.3)\end{array}$ \\
\hline 5 eme & $87(23.9)$ & $45(21.6)$ & $38(26.4)$ & $30(21.5)$ & $\begin{array}{l}15 \\
(21.0)\end{array}$ & $\begin{array}{l}15 \\
(22.3)\end{array}$ \\
\hline 4 eme & $93(23.1)$ & $63(25.2)$ & $29(20.1)$ & $29(19.2)$ & $\begin{array}{l}17 \\
(20.5)\end{array}$ & $\begin{array}{l}12 \\
(17.7)\end{array}$ \\
\hline 3 eme & $69(19.7)$ & $37(17.4)$ & $32(25.0)$ & $44(33.6)$ & $19(26.9)$ & $\begin{array}{l}25 \\
(42.7)\end{array}$ \\
\hline \multicolumn{7}{|l|}{$\begin{array}{l}\text { Possession of Average } \\
\text { spending money/week }\end{array}$} \\
\hline I have & $\begin{array}{l}294 \\
(73.6)\end{array}$ & 178(72.5) & $\begin{array}{l}106 \\
(74.1)\end{array}$ & $99(67.8)$ & $\begin{array}{l}56 \\
(68.9)\end{array}$ & $\begin{array}{l}43 \\
(67.2)\end{array}$ \\
\hline I do not have & $\begin{array}{l}106 \\
(26.4)\end{array}$ & $68(27.5)$ & $37(25.9)$ & $47(32.2)$ & $\begin{array}{l}25 \\
(31.1)\end{array}$ & $\begin{array}{l}21 \\
(32.8)\end{array}$ \\
\hline Parental Smoke (Yes) & $\begin{array}{l}145 \\
(38.1)\end{array}$ & $85(36.1)$ & $53(39.1)$ & $38(26.9)$ & $\begin{array}{l}18 \\
(22.8)\end{array}$ & $\begin{array}{l}20 \\
(32.2)\end{array}$ \\
\hline $\begin{array}{l}\text { SHS exposure inside home } \\
\text { (Yes) }\end{array}$ & $238(60.1)$ & $153(63.3)$ & $82(57.1)$ & $57(39.4)$ & $36(45.1)$ & $21(32.4)$ \\
\hline $\begin{array}{l}\text { SHS exposure outside home } \\
\text { (Yes) }\end{array}$ & $305(78.2)$ & 196(81.0) & 101(72.7) & 102(70.3) & $59(73.0)$ & $42(66.3)$ \\
\hline $\begin{array}{l}\text { Exposure to smoking media } \\
\text { messages (Yes) }\end{array}$ & $203(52.9)$ & $131(55.9)$ & $68(48.9)$ & $65(47.2)$ & $37(48.9)$ & $27(44.5)$ \\
\hline $\begin{array}{l}\text { Exposure to anti-smoking } \\
\text { media messages (Yes) }\end{array}$ & $240(64.9)$ & $154(67.4)$ & $78(59.2)$ & $75(55.5)$ & $44(58.9)$ & $30(50.6)$ \\
\hline $\begin{array}{l}\text { Exposure to tobacco industry } \\
\text { promotion (Yes) }\end{array}$ & $142(43.4)$ & $93(44.4)$ & $45(40.3)$ & $49(40.5)$ & $30(43.8)$ & $19(36.2)$ \\
\hline $\begin{array}{l}\text { Knowledge about harmful } \\
\text { effects of SHS(Yes) }\end{array}$ & $260(68.0)$ & $166(70.1)$ & $86(63.7)$ & $90(62.4)$ & $47(59.5)$ & $42(65.7)$ \\
\hline $\begin{array}{l}\text { school anti-smoking education } \\
\text { (Yes) }\end{array}$ & $119(31.8)$ & $76(32.3)$ & $40(30.3)$ & $51(37.4)$ & $29(38.4)$ & $22(36.2)$ \\
\hline $\begin{array}{l}\text { Favour toward smoking ban } \\
\text { (Yes) }\end{array}$ & $284(76.6)$ & $185(79.4)$ & $92(72.0)$ & $111(78.6)$ & $64(81.8)$ & $46(74.1)$ \\
\hline
\end{tabular}

a Weighted percentage

SHS: Secondhand Smoke

$\mathrm{n}=$ Unweighted count

\section{Determinants of current cigarette smoking and non-cigarette tobacco product use among male and female adolescents in Comoros}

Table 4 shows determinants of current cigarette smoking and non-cigarette tobacco product use among male and female adolescents in Comoros. Males were two times more likely to be current cigarette smokers compared to 
females (AOR=2.24;95\%Cl:1.39-3.63). Adolescents aged 13-15 years (AOR=3.11;95\%Cl:1.53-6.35) and 16 and above $(A O R=4.89 ; 95 \% \mathrm{Cl}: 2.56-9.37)$ were more likely to be current cigarette smokers than those 12 years and younger. $A$ similar association was observed among males but not females. Adolescents exposed to secondhand smoke inside $(A O R=3.88 ; 95 \% \mathrm{Cl}: 2.84-5.31)$ ) and outside (AOR=1.49; 95\% Cl: 1.08-2.03) their home were more likely to be current cigarette smokers compared to those who were not exposed. Similarly, exposure to secondhand smoke in the home was a determinant of current cigarette smoking among males (AOR=4.90;95\% Cl:3.95-6.08) and females (AOR=2.89; $95 \% \mathrm{Cl}: 1.35-6.19)$. However, exposure to secondhand smoke outside the home was a determinant of current cigarette smoking only among males ( $\mathrm{AOR}=1.72 ; 95 \% \mathrm{Cl}: 1.20-2.46)$ but not females ( $\mathrm{AOR}=1.13 ; 95 \% \mathrm{Cl}: 0.60-2.13)$. Exposure to tobacco industry promotion was found to be associated with current cigarette smoking among adolescents in general (AOR=2.90; 95\%Cl:2.21-3.80), and this was the case for both males (AOR=2.66;95\%Cl:1.86-3.82) and females $(A O R=3.44(; 95 \% \mathrm{Cl}: 1.92-6.17)$. However, parental smoke (AOR=1.20; 95\%Cl:0.78-1.87) and not exposed to antismoking education in schools ( $\mathrm{AOR}=0.97 ; 95 \% \mathrm{Cl}: 0.76-1.22)$ were not associated with current cigarette use.

Adolescents exposed to tobacco industry promotion were more likely to be current users of non-cigarette tobacco products than those not exposed to tobacco industry promotion (AOR=.2.58;95\%Cl:1.54-4.32). Similar relationship between exposure to tobacco industry promotion and non-cigarette tobacco use was observed among males $(A O R=2.58 ; 95 \% \mathrm{Cl}: 1.39-4.78)$ and females (AOR=2.54;95\% Cl:1.24-5.22). Adolescents who did not receive antismoking education in schools were $52 \%$ less likely to be current non-cigarette tobacco users (AOR=0.52;95\%Cl:0.320.85 ) than those not exposed to anti-smoking education in school. Among males, being knowledgeable about the harmful effects of smoking and SHS was a determinant of current use of non-cigarette tobacco products (AOR=1.75;95\%Cl:1.03-2.99). (See Table 4 for details)

Table 4: Determinants of current cigarette smoking and non-cigarette tobacco product use among male and female school-going adolescents. Global Youth Tobacco Survey, $2015(\mathrm{~N}=2,810)$ 


\begin{tabular}{|c|c|c|c|c|c|c|c|}
\hline \multirow[t]{2}{*}{ Characteristics } & \multirow[t]{2}{*}{ Variables } & \multicolumn{3}{|c|}{ Current cigarette smoker } & \multicolumn{3}{|c|}{$\begin{array}{l}\text { Current user of noncigarette } \\
\text { tobacco products }\end{array}$} \\
\hline & & $\begin{array}{l}\text { Total } \\
\text { AOR } \\
(95 \% \text { CI) }\end{array}$ & $\begin{array}{l}\text { Male AOR } \\
(95 \% \mathrm{CI})\end{array}$ & $\begin{array}{l}\text { Female } \\
\text { AOR } \\
(95 \% \mathrm{CI})\end{array}$ & $\begin{array}{l}\text { Total } \\
\text { AOR } \\
(95 \% \mathrm{CI})\end{array}$ & $\begin{array}{l}\text { Male } \\
\text { AOR } \\
(95 \% \text { CI) }\end{array}$ & $\begin{array}{l}\text { Female } \\
\text { AOR } \\
(95 \% \mathrm{CI})\end{array}$ \\
\hline \multirow[t]{2}{*}{ Sex } & male & $\begin{array}{l}2.24(1.39- \\
3.63)\end{array}$ & & & $\begin{array}{l}1.24(0.82- \\
1.86)\end{array}$ & & \\
\hline & Female & 1 & & & 1 & & \\
\hline \multirow[t]{4}{*}{ Age } & & & & & & & \\
\hline & $\leq 12$ years & 1 & 1 & 1 & 1 & 1 & 1 \\
\hline & \begin{tabular}{|l|}
$13-15$ \\
years
\end{tabular} & $\begin{array}{l}3.11(1.53- \\
6.35)\end{array}$ & $\begin{array}{l}4.44(1.69- \\
11.65)\end{array}$ & $\begin{array}{l}1.92(0.85- \\
4.34)\end{array}$ & $\begin{array}{l}1.04(0.34- \\
3.16)\end{array}$ & $\begin{array}{l}0.79(0.14- \\
4.35)\end{array}$ & $\begin{array}{l}1.28(0.41- \\
3.99)\end{array}$ \\
\hline & \begin{tabular}{|l|}
$\geq 16$ \\
years
\end{tabular} & $\begin{array}{l}4.89(2.56- \\
9.37)\end{array}$ & $\begin{array}{l}8.83(3.36- \\
23.21)\end{array}$ & $\begin{array}{l}2.34 \\
(0.91- \\
6.03)\end{array}$ & $\begin{array}{l}1.84(0.64- \\
5.32)\end{array}$ & $\begin{array}{l}1.64(0.28- \\
9.45)\end{array}$ & $\begin{array}{l}2.13(0.87- \\
5.26)\end{array}$ \\
\hline \multicolumn{8}{|l|}{ Grade } \\
\hline & $6 \mathrm{eme}$ & $\begin{array}{l}2.41 \\
(1.36- \\
4.27)\end{array}$ & $\begin{array}{l}3.56(1.26- \\
10.06)\end{array}$ & $\begin{array}{l}1.47(0.59- \\
3.63)\end{array}$ & $\begin{array}{l}0.85(0.49- \\
1.48)\end{array}$ & $\begin{array}{l}1.32(0.71- \\
2.43)\end{array}$ & $\begin{array}{l}0.57(0.22- \\
1.48)\end{array}$ \\
\hline & 5 eme & $\begin{array}{l}1.22(0.78- \\
1.90)\end{array}$ & $\begin{array}{l}1.01(0.50- \\
2.05)\end{array}$ & $\begin{array}{l}1.60(0.61- \\
4.20)\end{array}$ & $\begin{array}{l}0.72(0.43- \\
1.22)\end{array}$ & $\begin{array}{l}0.68(0.25- \\
1.82)\end{array}$ & $\begin{array}{l}0.80(0.38- \\
1.70)\end{array}$ \\
\hline & 4 eme & $\begin{array}{l}1.46(0.81- \\
2.62)\end{array}$ & $\begin{array}{l}1.70(0.84- \\
3.45)\end{array}$ & $\begin{array}{l}1.16(0.40- \\
3.31)\end{array}$ & $\begin{array}{l}0.62(0.38- \\
1.00)\end{array}$ & $\begin{array}{l}0.72(0.32- \\
1.65)\end{array}$ & $\begin{array}{l}0.52(0.25- \\
1.09)\end{array}$ \\
\hline & 3 eme & 1 & 1 & 1 & 1 & & 1 \\
\hline \multicolumn{8}{|l|}{$\begin{array}{l}\text { Possession of } \\
\text { Average } \\
\text { spending } \\
\text { money/week }\end{array}$} \\
\hline & I have & $\begin{array}{l}0.89(0.62- \\
1.26)\end{array}$ & $\begin{array}{l}0.85(0.57- \\
1.27\end{array}$ & $\begin{array}{l}0.96(0.61- \\
1.49)\end{array}$ & $\begin{array}{l}0.83(0.62- \\
1.12)\end{array}$ & $\begin{array}{l}0.66(0.37- \\
1.17) \\
\end{array}$ & $\begin{array}{l}1.14(0.67- \\
1.95)\end{array}$ \\
\hline & $\begin{array}{l}\text { I do not } \\
\text { have }\end{array}$ & 1 & 1 & 1 & 1 & 1 & 1 \\
\hline \multirow[t]{2}{*}{$\begin{array}{l}\text { Parental } \\
\text { Smoke }\end{array}$} & Yes & $\begin{array}{l}1.20(0.78- \\
1.87)\end{array}$ & $\begin{array}{l}0.95(0.58- \\
1.54)\end{array}$ & $\begin{array}{l}1.70(0.77- \\
3.76)\end{array}$ & $\begin{array}{l}0.92(0.40- \\
2.11)\end{array}$ & $\begin{array}{l}0.69(0.23- \\
2.06)\end{array}$ & $\begin{array}{l}1.22(0.52- \\
2.86)\end{array}$ \\
\hline & No & 1 & 1 & 1 & 1 & 1 & 1 \\
\hline \multirow[t]{2}{*}{$\begin{array}{l}\text { SHS exposure } \\
\text { inside home }\end{array}$} & Yes & $\begin{array}{l}3.88(2.84- \\
5.31)\end{array}$ & $\begin{array}{l}4.90(3.95- \\
6.08)\end{array}$ & $\begin{array}{l}2.89(1.35- \\
6.19)\end{array}$ & $\begin{array}{l}1.47(0.87- \\
2.48)\end{array}$ & $\begin{array}{l}1.98(0.94- \\
4.20)\end{array}$ & $\begin{array}{l}0.97(0.47- \\
2.02)\end{array}$ \\
\hline & No & 1 & 1 & 1 & 1 & 1 & 1 \\
\hline \multirow[t]{2}{*}{$\begin{array}{l}\text { SHS exposure } \\
\text { outside home }\end{array}$} & Yes & $\begin{array}{l}1.49(1.08- \\
2.03)\end{array}$ & $\begin{array}{l}1.72(1.20- \\
2.46)\end{array}$ & $\begin{array}{l}1.13(0.60- \\
2.13)\end{array}$ & $\begin{array}{l}1.45(0.87- \\
2.43)\end{array}$ & \begin{tabular}{|l}
$1.46(0.89-$ \\
$2.41)$
\end{tabular} & $\begin{array}{l}1.42(0.52- \\
3.88)\end{array}$ \\
\hline & No & 1 & 1 & 1 & 1 & 1 & 1 \\
\hline \multirow{2}{*}{$\begin{array}{l}\text { Exposure to } \\
\text { smoking media } \\
\text { messages }\end{array}$} & Yes & $\begin{array}{l}0.74(0.48- \\
1.14)\end{array}$ & $\begin{array}{l}0.59(0.24- \\
1.48)\end{array}$ & $\begin{array}{l}1.21(0.43- \\
3.41)\end{array}$ & $\begin{array}{l}0.69(0.37- \\
1.27)\end{array}$ & $\begin{array}{l}0.68(0.34- \\
1.37)\end{array}$ & $\begin{array}{l}0.77(0.14- \\
4.09)\end{array}$ \\
\hline & No & 1 & 1 & 1 & 1 & 1 & 1 \\
\hline \multirow{2}{*}{$\begin{array}{l}\text { Exposure to } \\
\text { anti-smoking } \\
\text { media } \\
\text { messages }\end{array}$} & Yes & 1 & 1 & & 1 & 1 & 1 \\
\hline & \begin{tabular}{|l} 
No \\
\end{tabular} & $\begin{array}{l}0.65(0.47- \\
0.90)\end{array}$ & $\begin{array}{l}0.53(0.24- \\
1.48) \\
\end{array}$ & $\begin{array}{l}0.96(0.33- \\
2.81) \\
\end{array}$ & $\begin{array}{l}0.80(0.41- \\
1.54)\end{array}$ & $\begin{array}{l}0.64(0.32- \\
1.29) \\
\end{array}$ & $\begin{array}{l}1.09(0.23- \\
5.26)\end{array}$ \\
\hline \multirow{4}{*}{$\begin{array}{l}\text { Exposure to } \\
\text { tobacco } \\
\text { industry } \\
\text { promotion } \\
\text { Knowledge } \\
\text { about harmful } \\
\text { effects of }\end{array}$} & Yes & $\begin{array}{l}2.90(2.21- \\
3.80)\end{array}$ & $\begin{array}{l}2.66(1.86- \\
3.82)\end{array}$ & $\begin{array}{l}3.44(1.92- \\
6.17)\end{array}$ & $\begin{array}{l}2.58(1.54- \\
4.32)\end{array}$ & $\begin{array}{l}2.58(1.39- \\
4.78)\end{array}$ & $\begin{array}{l}2.54(1.24- \\
5.22)\end{array}$ \\
\hline & No & 1 & 1 & 1 & 1 & 1 & 1 \\
\hline & Yes & 1 & 1 & 1 & 1 & 1 & 1 \\
\hline & No & $\begin{array}{l}1.12(0.83- \\
1.52)\end{array}$ & $\begin{array}{l}1.04(0.68- \\
1.60)\end{array}$ & $\begin{array}{l}1.37(0.80- \\
2.36)\end{array}$ & $\begin{array}{l}1.36(0.85- \\
2.19)\end{array}$ & $\begin{array}{l}1.75(1.03- \\
2.99)\end{array}$ & $\begin{array}{l}1.03(0.52- \\
2.05)\end{array}$ \\
\hline
\end{tabular}




\begin{tabular}{|c|c|c|c|c|c|c|c|}
\hline $\begin{array}{l}\text { smoking and } \\
\text { SHS }\end{array}$ & & & & & & & \\
\hline \multirow{2}{*}{$\begin{array}{l}\text { school anti- } \\
\text { smoking } \\
\text { education }\end{array}$} & Yes & 1 & 1 & 1 & 1 & 1 & 1 \\
\hline & No & $\begin{array}{l}0.97(0.76- \\
1.22)\end{array}$ & $\begin{array}{l}1.04(0.68- \\
1.59)\end{array}$ & $\begin{array}{l}0.84(0.55- \\
1.29)\end{array}$ & $\begin{array}{l}0.52(0.32- \\
0.85)\end{array}$ & $\begin{array}{l}0.51(0.29- \\
0.88)\end{array}$ & $\begin{array}{l}0.56(0.23- \\
1.44)\end{array}$ \\
\hline \multirow{2}{*}{$\begin{array}{l}\text { Favour toward } \\
\text { smoking ban }\end{array}$} & Yes & 1 & 1 & 1 & 1 & 1 & 1 \\
\hline & No & $\begin{array}{l}1.16(0.80- \\
1.67)\end{array}$ & $\begin{array}{l}0.99(0.65- \\
1.52)\end{array}$ & $\begin{array}{l}1.58(0.81- \\
3.08)\end{array}$ & $\begin{array}{l}0.90(0.56- \\
1.45)\end{array}$ & $\begin{array}{l}0.68(0.26- \\
1.78)\end{array}$ & $\begin{array}{l}1.26(0.90- \\
1.77)\end{array}$ \\
\hline
\end{tabular}

SHS- Second hand smoke

$\square \mathrm{p}<0.05$

\section{Discussion}

This is the first nationally representative study of school-going adolescents in Comoros regarding their tobacco use behaviour (cigarette smoking and use of non-cigarette tobacco products). We found that $14.3 \%$ of school-going adolescents in Comoros were smoking cigarettes, with a higher prevalence observed in males than females. Our prevalence was higher than those reported in studies conducted in Ghana(7), Malawi(23), and East African countries(Sudan and South Sudan, Kenya, Tanzania, and Ethiopia) $(21,24)$. On the other hand, our prevalence of current cigarette smoking was lower than the rates reported in Madagascar(9), Ville du Sud, Cote d'Ivoire(25) and Southeast Nigeria(26). In addition, 5.8\% of school-going adolescents in Comoros were current users of non-cigarette tobacco products, with slight difference users observed among males than females. Our rate is lower than the rates reported in similar studies conducted in Madagascar(9), the Republic of Congo(8), Sudan and South Sudan(21), but higher than the prevalence reported in a study conducted in Ilala Municipality, Tanzania(27). Our findings suggest the need for youth-friendly tobacco control policies and interventions that are gender-sensitive. Even though the prevalence of non-cigarette tobacco products is lower than cigarette smoking, non-cigarette tobacco products such as cigars and pipes are equally harmful as cigarettes. Thus, it is important that, in addition to cigarettes, the adverse effects of non-cigarette tobacco products should be part of tobacco control interventions such as public education and advocacy strategies targeting adolescents in Comoros.

Our findings indicate a high level of tobacco use among adolescents exposed to secondhand smoke both within and outside the home in Comoros. Adolescents exposed to secondhand smoke inside and outside the home were more likely to be current cigarette smokers, observed in both males and females. In contrast, exposure to secondhand smoke inside and outside the house was not significantly associated with using non-cigarette tobacco products. Our findings are in line with a similar study conducted in Madagascar, Sudan, and South Sudan in which exposure to secondhand smoking outside the home was found to be associated with current cigarette smoke $(9,21)$. At the same time, our findings contrast with a Madagascan study in which secondhand smoke inside the home was associated with non-cigarette tobacco products use(9) and a Congolese study in which having a parent or friend who smokes was associated with using smokeless tobacco(8). Our findings highlight the strong influence of familial and outdoor smoking on adolescents' cigarette smoking behaviour, as reported in previous studies $(28,29)$. Such influence on youth tobacco use is explained by the fact that adolescents tend to indulge in high-risk behaviours practised by their parents, siblings, or community members because they consider it normal(30). Our finding suggests that a tobacco prevention and control interventions targeting adolescents in Comoros should design educational campaigns for parents and other household members. Such a campaign should inform household members of the extent of their influence on their adolescent smoking behaviour and provide ways to prevent adolescents from using tobacco 
products. The influence of secondhand smoke outside the home on cigarette smoking among adolescents in our study may be due to the ineffective implementation of the law prohibiting tobacco use in public places and workplaces in Comoros(31). The weak implementation of smoke-free laws has been attributed to inconsistencies and contrasting provisions within tobacco control laws in Comoros(18,31). For instance, based on the current provisions, it is difficult to ascertain whether smoking is prohibited in primary/secondary schools, shops and Casinos(31). Moreover, there is no clear indication of what agency is responsible, and there is no clear duty to enforce the smoke-free law(31). Going forward, smoke-free tobacco laws need to be revised to remove any ambiguity in their interpretation. In addition, in line with article 8 of the WHO-FCTC(32), the legislation should indicate the agency responsible for enforcing the law. Furthermore, the ineffective implementation of tobacco laws in Comoros maybe due to the lack of follow-up in the implementation of health policies by successive governments due to political instability in the country, and sometimes variability in the implementation of health policies between the central government in Grande Comore and the local semi-autonomous governments in the other islands (Anjouan and Moheli) due to differences in their political ideologies(33). Further studies are needed to explore the impact of previous political insecurity and instability in the implementation of tobacco laws in Comoros.

Consistent with other studies, and similar studies conducted in other developing countries(7-10, 21, 34), exposure to tobacco industry promotion was significantly associated with cigarette smoking and non-cigarette tobacco use in our study. The increased exposure of adolescents to tobacco industry promotion and its association with tobacco use may be due to the increased penetration of tobacco companies into the Comorian market, which may be attributed to low tobacco taxes, partial ban on tobacco promotion, and weak regulation of anti-tobacco promotion laws. Previous research has demonstrated that countries with less comprehensive and weak tobacco promotion, advertisement, and sponsorship regulations have a higher rate of adolescent tobacco use compared to those with comprehensive and stricter laws, which are fully implemented $(35,36)$. Our finding further supports the link between tobacco product promotion and adolescent tobacco use. Currently, there are ambiguities in the interpretation of Comoros's tobacco promotion and advertisement laws, and these legislations are not strictly in line with WHO-FCTC Article 13 guidelines(31). The law allows tobacco product sales via the internet and point of sale, advertisements and promotions, and tobacco product display. In addition, the law does not address vending machine sales of tobacco products and does not explicitly address cross-border advertising broadcast from outside of Comoros and does not address retailer incentive programs(31). Comoros' weak and ambiguous tobacco advertisement and promotion laws provide an opportunity for the tobacco industry to identify loopholes in current legislation or find innovative ways to promote their products among adolescents. A case in point is the use of the internet to promote and sell their products. Compared with other exposure channels, the internet has been reported to be a leading conduit used by tobacco companies to promote, advertise, and sell their products to adolescents in developed countries $(37,38)$ and this may explain the insignificant association observed between exposure to smoking media messages and cigarette use and non-cigarette use in our study.. Exposure to tobacco promotion via the internet has been associated with traditional and alternative forms of tobacco use $(38,39)$. Currently, it is unknown whether such exposure channels (e.g., internet, point of sales, etc.) are widely used by tobacco companies in Comoros and that influence adolescent tobacco use among adolescents. Further studies need to explore this area of enquiry. Given the adverse health effects of tobacco use and the increase in tobacco-related chronic conditions in Comoros, it is important that the existing tobacco industry promotion, advertisement, and sponsorship laws are revised and implemented consistent with WHO-FCTC article 13 guidelines(40). Such interventions will help prevent adolescents from becoming adult smokers.

Consistent with previous systematic reviews (41), we observed that adolescents who were not exposed to antismoking education in their schools were less likely to be current cigarette and non-cigarette tobacco users. Our

Page $14 / 20$ 
finding suggests that anti-smoking education are either not done in schools in Comoros or if they are done has not been effective in preventing adolescents from using tobacco products. Previous systematic reviews have reported that school based tobacco prevention interventions have no effect on adolescent tobacco use $(41,42)$. The ineffectiveness of tobacco prevention interventions maybe due to the strong peer and family influence as it has been previously reported in other studies $(43,44)$. In order to archive an impact, school based tobacco prevention interventions such as anti-tobacco educational programs should be vigorous and integrated within the country school curriculum, and such an approach should be linked with family and community tobacco use prevention programs for it to have a long term impact to preventing adolescent tobacco use $(44,45)$.

It is important for readers to bear in mind the following limitations when interpreting our findings. Given the crosssectional design employed in this study, no causal relationship can be made between the outcome and independent variables. Also, the study is prone to recall bias, given that responses were based on participant self-reports. In addition, our findings are not representative of all adolescents in Comoros as only school-going adolescents were included in the study. Only individual-level measures were used based on the GYTS questionnaire. Other variables relating to national tobacco control programs or policies in Comoros that could have influenced tobacco use among adolescents were not included. Furthermore, we could not determine whether adolescent tobacco use behaviour varied in the three islands that constitute Comoros and the association between tobacco use and peer smoking as data on peer smoking was not provided in the dataset. Nonetheless, this study is the first study that examines the prevalence and correlates of tobacco use among school-going adolescents in Comoros using the most recent Comoros GYTS dataset and provides the baseline insight for future studies into tobacco use behaviour in Comoros.

\section{Conclusion}

Our study finds that one in seven school-going adolescents in Comoros smoke cigarettes, with a significant gap between males and females. Also, in our study, approximately one in 20 school-going adolescents use non-cigarette tobacco products, but no significant gender gap exists. Exposure to secondhand smoke in and outside the house was significantly associated with the current use of cigarettes. Irrespective of gender, exposure to tobacco industry promotion was significantly associated with the current use of non-cigarette tobacco products among school-going adolescents in Comoros. In addition, adolescents who received anti-smoking education in schools in our study were less likely to be current non-cigarette tobacco users.

Our findings suggest the need to implement the following recommendations to help to prevent and reduce tobacco use among school-going adolescents in Comoros.

- In addition to cigarettes, the adverse effects of non-cigarette tobacco products should be part of tobacco control interventions such as public education and advocacy strategies targeting adolescents in Comoros.

- Tobacco prevention and control interventions targeting adolescents in Comoros should design educational campaigns for parents and other household members. Such a campaign should inform household members of the extent of their influence on their adolescent smoking behaviour and provide ways how they can prevent adolescents from smoking tobacco.

- Tobacco smoke-free laws need to be revised to remove any ambiguity in their interpretation and implemented in accordance with the WHO-FCTC Article 8 guidelines.

- Existing tobacco industry promotion advertisement and sponsorship laws need to be revised and implemented consistent with WHO-FCTC article 13 guidelines. Such interventions will help prevent adolescents from becoming adult smokers.

Page $15 / 20$ 
- School based tobacco prevention interventions integrated within the country school curriculum, and such an approach should be linked with family and community tobacco use prevention programs

\section{Abbreviations}

Cl: Confidential Intervals

FCTC: Framework Convention on Tobacco Control

GYTS: Global Youth Tobacco Survey

GTS: Global Tobacco Surveillance

OR: odds ratio

SHS: second-hand smoke

SPSS: Statistical Package for The Social Sciences

WHO: World Health Organization

\section{Declarations}

\section{Availability of data}

The dataset informing the findings of this study is freely available via the WHO NCD Microdata Repository https://extranet.who.int/ncdsmicrodata/index.php/catalog/123

\section{Competing interests}

The authors declared no conflict of interest

\section{Funding}

No funding was obtained for this study.

\section{Authors' contributions}

PBJ, SAK and JAK conceptualised the study. PBJ designed the data analysis plan, conducted the analysis, interpreted the results, and wrote the first draft of the manuscript. SAK participated in the interpretation of the results and contributed to writing the manuscript. JAK and CK, participated in the interpretation of the results and edited the manuscript. All authors read and approved the final manuscript.

\section{Acknowledgements}

We want to thank the high school students who participated in the 2015 Sierra Comoros Global Youth Tobacco Survey. This paper uses data from the Global Youth Tobacco Survey (GYTS). GYTS is supported by the World Health Organization and the US Centers for Disease Control and Prevention. 


\section{References}

1. WHO. WHO report on the global tobacco epidemic, 2019 Country Profile: Sierra

Leone. https://www.who.int/tobacco/surveillance/policy/country_profile/sle.pdf?ua=1 Accessed 22 June 2021. 2019.

2. Öberg M, Jaakkola MS, Woodward A, Peruga A, Prüss-Ustün A. Worldwide burden of disease from exposure to second-hand smoke: a retrospective analysis of data from 192 countries. The Lancet. 2011;377(9760):139-46.

3. Ogilvie D, Gruer L, Haw S. Young people\&\#039;s access to tobacco, alcohol, and other drugs. BMJ. 2005;331(7513):393.

4. Palipudi KM, Gupta PC, Sinha DN, Andes LJ, Asma S, McAfee T, et al. Social determinants of health and tobacco use in thirteen low and middle income countries: evidence from Global Adult Tobacco Survey. PLoS One. 2012;7(3):e33466.

5. US Department of Health and Human Services. The tobacco industry's influences on the use of tobacco among youth. Preventing Tobacco Use Among Youth and Young Adults A Report of the Surgeon General Rockland, MD: US Department of Health and Human Services, Centers for Disease Control and Prevention, National Center for Chronic Disease Prevention and Health Promotion, Office on Smoking and Health. 2012.

6. MacKay J. The tobacco problem: commercial profit versus health-the conflict of interests in developing countries. Preventive medicine. 1994;23(4):535-8.

7. Mamudu HM, Veeranki SP, John RM. Tobacco Use Among School-Going Adolescents (11-17 Years) in Ghana. Nicotine \& Tobacco Research. 2013;15(8):1355-64.

8. Rudatsikira E, Muula AS, Siziya S. Current use of smokeless tobacco among adolescents in the Republic of Congo. BMC Public Health. 2010;10(1):16.

9. Veeranki SP, Mamudu HM, John RM, Ouma AE. Prevalence and correlates of tobacco use among schoolgoing adolescents in Madagascar. Journal of epidemiology and global health. 2015;5(3):239-47.

10. Chido-Amajuoyi OG, Mantey DS, Clendennen SL, Pérez A. Association of tobacco advertising, promotion and sponsorship (TAPS) exposure and cigarette use among Nigerian adolescents: implications for current practices, products and policies. BMJ global health. 2017;2(3):e000357.

11. BBC. Comoros country profile. https://www.bbc.com/news/world-africa-13229685. Accessed 12 August 2021. 2021.

12. Abasse KS, Abbas M, Mohamed KS, Baig MMFA, Habib M, Cote A, et al. A Comparative Study of the Health Care Delivery Systems in the Indian Ocean: What can Comoros Islands Learn from Mauritius and Seychelles? Journal of Health Care for the Poor and Underserved. 2021;32(3):1236-64.

13. World Ban Group. The World Bank in Comoros. https://www.worldbank.org/en/country/comoros/overview Accessed 11 August 2021. 2020.

14. World Ban Group. Data-Prevalence of current tobacco use (\% of adults) Comoros. https://data. worldbank.org/indicator/SH.PRV.SMOK?end=2018\&locations=KM\&start=2007\&view=chart 
Accessed 12 August 2021. 2021.

15. WHO. Country Cooperation Strategy at a glance Comoros-Health

Situation. https://www.afro.who.int/publications/un-apercu-de-la-strategie-de-cooperation-comores. Accessed 12 August 2021. 2021.

16. Ali RAB, Hannoun Z, Harraqui K, Zeghari L, Aboussaleh Y, Mohamed S, et al. Profile of diabetes and cardiovascular risk factors in adults Anjouan Island (Comoros). The Pan African medical journal. 2019;33:140-.

17. CEIC. Comoros KM: Cause of Death: by Non-Communicable Diseases: \% of

Total. https://www.ceicdata.com/en/comoros/health-statistics/km-cause-of-death-by-noncommunicable-diseases-of-total Accessed 12 August 2021. 2021.

18. Campaign for Tobacco-Free Kids. Comoros Tobacco Control

Policies. https://www.tobaccocontrollaws.org/legislation/factsheet/policy_status/comoros Accessed 10 August 2021. 2020.

19. WHO. Global Youth Tobacco Survey

2015.https://extranet.who.int/ncdsmicrodata/index.php/catalog/123/study-description. Accessed 12 July 2021. 2021.

20. WHO. NCD Microdata Repository-Global Youth Tobacco Survey 2015 Comoros, 2015. https://extranet.who.int/ncdsmicrodata/index.php/catalog/123/related-materials. Accessed 12 July 2021. 2021.

21. Atari DO. Gender differences in the prevalence and determinants of tobacco use among school-aged adolescents (11-17 years) in Sudan and South Sudan. The Pan African medical journal. 2014;18:118-.

22. James PB KS, Kabba JA, Kitchen C. Tobacco use among School-going Adolescents in Comoros: A Secondary Analysis of the 2015 Comoros Global Youth Tobacco Survey. Research Square(Preprint) https://www.researchsquare.com/article/rs-838524/v1

2021.

23. Muula A, Siziya S, Rudatsikira E. Prevalence and correlates of cigarette smoking among adolescents in Malawi: results from the Global Youth Tobacco Survey 2005. Tanzania Journal of Health Research. 2008;10(3):16676.

24. Tezera N, Endalamaw A. Current Cigarette Smoking and Its Predictors among School-Going Adolescents in East Africa: A Systematic Review and Meta-Analysis. International journal of pediatrics. 2019;2019:4769820-.

25. Siziya S, Rudatsikira E, Muula AS. Factors associated with current cigarette smoking among adolescents in Ville du Sud, Cote d'Ivoire. Le Mali medical. 2007;22(4):40-6.

26. Itanyi IU, Onwasigwe CN, Mclntosh S, Bruno T, Ossip D, Nwobi EA, et al. Disparities in tobacco use by adolescents in southeast, Nigeria using Global Youth Tobacco Survey (GYTS) approach. BMC Public Health. 2018;18(1):317. 
27. Kaduri P, Kitua H, Mbatia J, Kitua AY, Mbwambo J. Smokeless tobacco use among adolescents in Ilala Municipality, Tanzania. Tanzania Journal of Health Research. 2008;10(1):28-33.

28. Mays D, Gilman SE, Rende R, Luta G, Tercyak KP, Niaura RS. Parental smoking exposure and adolescent smoking trajectories. Pediatrics. 2014;133(6):983-91.

29. Vuolo M, Staff J. Parent and child cigarette use: a longitudinal, multigenerational study. Pediatrics. 2013;132(3):e568-e77.

30. Coley RL, Votruba-Drzal E, Schindler HS. Fathers' and Mothers' Parenting Predicting and Responding to Adolescent Sexual Risk Behaviors. Child Development. 2009;80(3):808-27.

31. Campaign for Tobacco-Free Kids. Tobacco Control Laws. Legislation by Country-

Comoros. https://www.tobaccocontrollaws.org/legislation/country/comoros/sf-indoor. Accessed 14 August 2021. 2020.

32. WHO. WHO-FCTC. Guidelines for implementation of Article 8. Guidelines on the protection from exposure to tobacco smoke. https://www.who.int/fctc/guidelines/adopted/article_8/en/ Accessed 15 August 2021. 2021.

33. Mohamed KS, Abasse, K.S., Abbas, M., Sintali, D.N., Baig, M.M.F.A. and Cote, A. An Overview of Healthcare Systems in Comoros: The Effects of Two Decades of Political Instability. Annals of Global Health. 2021;87(1):84.

34. Cho SM, Saw YM, Latt NN, Saw TN, Htet H, Khaing M, et al. Cross-sectional study on tobacco advertising, promotion and sponsorship (TAPS) and violations of tobacco sale regulations in Myanmar: do these factors affect current tobacco use among Myanmar high school students? BMJ open. 2020;10(2):e031933-e.

35. World Health Organization. WHO report on the global tobacco epidemic 2015: raising taxes on tobacco: World Health Organization; 2015.

36. Tafawa AO, Viswanath K, Kawachi I, Williams DR. Mass media exposure, social stratification, and tobacco consumption among Nigerian adults. Cancer Causes \& Control. 2012;23(1):45-55.

37. Dunlop S, Freeman B, Perez D. Exposure to internet-based tobacco advertising and branding: results from population surveys of Australian youth 2010-2013. Journal of medical Internet research. 2016;18(6):e5595.

38. Singh T, Agaku IT, Arrazola RA, Marynak KL, Neff LJ, Rolle IT, et al. Exposure to advertisements and electronic cigarette use among US middle and high school students. Pediatrics. 2016;137(5).

39. Fulmer EB, Neilands TB, Dube SR, Kuiper NM, Arrazola RA, Glantz SA. Protobacco media exposure and youth susceptibility to smoking cigarettes, cigarette experimentation, and current tobacco use among US youth. PLoS One. 2015;10(8):e0134734.

40. WHO. WHO-FCTC. Guidelines for implementation of Article 13. Guidelines on tobacco advertising, promotion and sponsorship. https://www.who.int/fctc/guidelines/adopted/article_13/en/ . Accessed 15 August 2021. 2021.

41. Wiehe SE, Garrison MM, Christakis DA, Ebel BE, Rivara FP. A systematic review of school-based smoking prevention trials with long-term follow-up. Journal of Adolescent Health. 2005;36(3):162-9. 
42. Thomas RE, McLellan J, Perera R. School-based programmes for preventing smoking. Evidence-Based Child Health: A Cochrane Review Journal. 2013;8(5):1616-2040.

43. Van Minh H, Hai PT, Giang KB, Nga PQ, Khanh PH, Lam NT, et al. Effects of individual characteristics and school environment on cigarette smoking among students ages 13-15: A multilevel analysis of the 2007 Global Youth Tobacco Survey (GYTS) data from Vietnam. Global Public Health. 2011;6(3):307-19.

44. Talley B, Masyn K, Chandora R, Vivolo-Kantor A. Multilevel analysis of school anti-smoking education and current cigarette use among South African students. The Pan African medical journal. 2017;26:37-.

45. Flay BR. School-based smoking prevention programs with the promise of long-term effects. Tob Induc Dis. 2009;5(1):6.

\section{Supplementary Files}

This is a list of supplementary files associated with this preprint. Click to download.

- Additionalfile1STROBEchecklistforcrosssectionalstudies.pdf 